\title{
Blenderized feeding formulas with nutritious and inexpensive foods
}

\author{
Dieta enteral manipulada com alimentos \\ com qualidade nutricional e baixo custo
}

\author{
Ana Paula Lança BENTO' \\ Rosa Wanda DIEZ GARCIA ${ }^{1}$ \\ Alceu Afonso JORDÃO JÚNIOR ${ }^{1}$
}

\section{A B S T R A C T}

\section{Objective}

To propose an inexpensive blenderized tube feeding formula consisting of foods with standard nutritional composition that meets the nutritional requirements of individuals aged more than 51 years.

\section{Methods}

The enteral diets were formulated mainly with fresh foods and tested for their physical (homogeneity, stability, osmolality, pH, and flow rate) and chemical (moisture, ash, protein, lipids, energy, crude fiber, vitamin C, calcium, iron, magnesium, and zinc) characteristics. The cost was determined by surveying item prices in supermarkets and stores that specialize in nutritional support.

\section{Results}

The blenderized tube feeding formula was stable and homogeneous, and had slightly acidic $\mathrm{pH}$, hypertonic osmolality $(603 \mathrm{mOsm} / \mathrm{kg})$, and flow rate comparable with gravity drip (21 minutes). Proximate composition analysis indicated appropriate levels of proteins, lipids, vitamin C, and zinc. The mean cost of 2000kcal of the standard blenderized tube feeding formula was $R \$ 12.3 \pm 1.4$, which is $70 \%$ cheaper than the mean cost of similar commercial enteral formulas.

\section{Conclusion}

The planned diet can be an excellent choice for patients using blenderized tube feeding formulas as it consisted of habitual food items, had physical and nutritional quality, and was inexpensive.

Keywords: Cost and cost analysis. Diet. Enteral nutrition.

\footnotetext{
1 Universidade de São Paulo, Faculdade de Medicina de Ribeirão Preto, Departamento de Clínica Médica. Av. Bandeirantes, 3900, Monte Alegre, 14049-900, Ribeirão Preto, SP, Brasil. Correspondência para/Correspondence to: APL BENTO. E-mail: <anapaulabentto@gmail.com>.

Article based on the doctoral dissertation of APL BENTO, intitled "Elaboração de dietas enterais manipuladas, análise de sua composição nutricional e qualidade microbiológica”. Universidade de São Paulo; 2010.

Support: Conselho Nacional de Desenvolvimento Científico e Tecnológico (Process no 133579/2007-7).
} 


\section{RE S U M O}

\section{Objetivo}

Propor uma formulação de dieta enteral manipulada com alimentos com composição nutricional padrão que atendam às necessidades nutricionais de pessoas com idade acima de 51 anos e que tenha baixo custo.

\section{Métodos}

As dietas enterais foram formuladas principalmente com alimentos in natura e testadas quanto às características físicas (homogeneidade, estabilidade, osmolalidade, pH e fluidez) e químicas (umidade, cinzas, proteína, lipídeos, energia, fibra bruta, vitamina C, cálcio, ferro, magnésio e zinco). O custo foi obtido por pesquisa de preço em supermercados e lojas especializadas em suporte nutricional.

\section{Resultados}

A dieta enteral manipulada apresentou-se estável, homogênea, $\mathrm{pH}$ levemente ácido, osmolalidade hipertônica $(603 \mathrm{mOsm} / \mathrm{kg})$ e fluidez compatível com o gotejamento gravitacional (21 minutos). A avaliação centesimal demonstrou adequação para proteína, lipídeo, vitamina C, ferro e zinco. O custo médio de $2000 \mathrm{kcal}$ de dieta enteral padrão foi de $R \$ 12,3 \pm 1,4$, o que representa um custo $70 \%$ menor, em relação ao custo médio de dietas enterais industrializadas semelhantes a estas disponiveis no mercado.

\section{Conclusão}

A dieta planejada pode ser uma excelente escolha para o paciente em uso de nutrição enteral domiciliar, foi elaborada com alimentos comuns ao hábito alimentar, apresentam qualidade física e nutricional e são de baixo custo.

Palavras-chave: Custo e analise de custo. Dieta. Nutrição enteral.

\section{INTRODUCTION}

Indication of home enteral nutrition has been increasing in the last years secondary to many factors, such as the increasing prevalence of chronic diseases, especially in older adults, who compose most home enteral nutrition patients [1].

The drive to reduce costs and humanize healthcare allows patients to return home and receive treatment at a familiar, comfortable, and safe environment [2].

The prevalence of home enteral nutrition has been investigated in many countries throughout the world, and it is estimated to be 460 patients/one million inhabitants in the United States, 280 patients/one million inhabitants in England, and 74.6 patients/one million inhabitants in Spain [3]. In Brazil no nationwide study has been conducted to estimate this prevalence. However, some regional studies have been published in the scientific literature, such as one from the Federal District, which found a prevalence of 176 patients/one million inhabitants [4].
Individuals who depend on this therapy use it for a long time, and for some, it is challenging to adhere to this therapy at home because of its cost as this therapy is not always fully covered by the healthcare system. In this sense, diets made of regular foods may be safely indicated.

Blenderized Tube Feeding Formulas (BTFFs), defined herein as formulas mainly composed of fresh foods, should be considered important for the maintenance of home enteral nutrition because they can be prepared using the foods consumed by the family and be an alternative to Commercial Enteral Formulas (CEFs). Another advantage of BTFFs is the presence of bioactive compounds known as polyphenols, glucosinolates, and carotenoids, which may play many beneficial roles in human health, such as antioxidant activity, immune system stimulation, reduction of platelet aggregation, modulation of hormone metabolism, and reduction of blood pressure $[5,6]$.

The scientific literature has few studies on BTFFs with adequate nutritional and 
microbiological quality that can be safely recommended by health professionals [7-12]. For this reason, BTFFs have been disregarded because of a lack of scientific arguments in their favor. Although little suspicion has been raised on the microbiological quality of CEFs, studies had found high levels of contamination in them [13-16] and in BTFF, so both should be carefully prepared under rigorous hygienic conditions.

Studies that attempt to find BTFF formulations with nutritional quality that meets the requirements of their users and that may be prescribed safely by professionals are necessary to guarantee home enteral nutrition.

The objective of this study was to propose an inexpensive blenderized tube feeding formula made of foods with standard nutritional composition that meets the nutritional requirements of individuals aged more than 51 years.

\section{METHODS}

The Standard Blenderized Tube Feeding Formula was formulated with fresh and processed foods. The nutritional composition of these items was given by the Food Composition Table (TACO) [17], except for skim milk, whose nutritional composition was given by the table created by Philippi [18], and for the dietary supplement, whose nutritional data were taken from the manufacturer's label (Table 1). The flow rate, stability, and homogeneity of the formulated diet was analyzed by the laboratory of Dietetic Technique of the Universidade de São Paulo of Ribeirão Preto (SP), which also determined how the formula should be prepared (how the raw foods should be cooked, for how long, and how long to blend them). Table 2 shows the food ingredients and the respective amounts.

Blenderized Tube Feeding Formulas preparation consisted of three stages: stage I: the raw foods (rice, carrots, and ground beef) were cooked together in the same pot. The rice, carrot, and ground beef proportions were calculated using the cooking factors established by Ornellas [19], which were 2.5, 0.9, and 0.7,

Table 1. Nutritional information of the food supplement used in the blenderized tube feeding formula (portion of $31.5 g-2$ tablespoons).

\begin{tabular}{lr}
\hline Nutrients & Amount \\
\hline Energy $(\mathrm{kcal})$ & 110.0 \\
Carbohydrates $(\mathrm{g})$ & 18.0 \\
Proteins $(\mathrm{g})$ & 7.6 \\
Total fats $(\mathrm{g})$ & 1.0 \\
Dietary fibers $(\mathrm{g})$ & 2.2 \\
Calcium $(\mathrm{mg})$ & 350.0 \\
Iron $(\mathrm{mg})$ & 6.3 \\
Sodium $(\mathrm{mg})$ & 112.0 \\
Potassium $(\mathrm{mg})$ & 387.0 \\
Phosphorus $(\mathrm{mg})$ & 196.0 \\
Magnesium $(\mathrm{mg})$ & 109.0 \\
Manganese $(\mathrm{mg})$ & 1.0 \\
Copper $(\mathrm{mg})$ & 405.0 \\
Zinc $(\mathrm{mg})$ & 3.2 \\
Vitamin A $(\mu \mathrm{g} \mathrm{RE})$ & 228.0 \\
Vitamin D $(\mu \mathrm{g})$ & 2.3 \\
Vitamin E $(\mathrm{mg} \mathrm{TE})$ & 2.0 \\
Vitamin K $(\mu \mathrm{g})$ & 1.1 \\
Vitamin C $(\mathrm{mg})$ & \\
Vitamin B6 $(\mathrm{mg})$ & 20.0 \\
Vitamin B12 $(\mathrm{mg})$ & \\
\hline
\end{tabular}

Table 2. Foods in the Blenderized Tube Feeding Formula (BTFF) in grams/milliliters and cooking units.

\begin{tabular}{lcc}
\hline \multirow{2}{*}{ Food } & \multicolumn{2}{c}{ BTFF } \\
\cline { 2 - 3 } & Amount $(\mathrm{g} / \mathrm{mL})$ & Cooking unit \\
\hline Skim milk & 1350 & $9.0^{\mathbf{a}}$ \\
Refined sugar & 120 & $5.0^{\mathbf{b}}$ \\
Maltodextrin & - & - \\
Raw rice & 40 & $2.0^{\mathbf{b}}$ \\
Cooked beans & 100 & $4.0^{\mathbf{b}}$ \\
Raw ground beef & 140 & $4.0^{\mathbf{b}}$ \\
Chopped raw carrot & 140 & $7.0^{\mathbf{b}}$ \\
Chopped onion & 40 & $3.0^{\mathbf{b}}$ \\
Soybean oil & 24 & $3.0^{\mathbf{b}}$ \\
Canola oil & 16 & $2.0^{\mathbf{b}}$ \\
Food supplement & 30 & $2.0^{\mathbf{b}}$ \\
Soybean extract & 22 & $1.5^{\mathbf{b}}$ \\
Orange juice & 300 & $2.0^{\mathbf{a}}$ \\
\hline
\end{tabular}

Note: ${ }^{\text {a } 190 m L ~ g l a s s ; ~}{ }^{\text {b}}$ Tablespoon 
respectively. Beans cooked in a pressure cooker for 30 minutes were added to the mixture. These foods were placed in a pot containing $150 \mathrm{~mL}$ of boiling water and cooked in low heat (using the small burner of standard stoves) for approximately 15 minutes. Stage II: once the raw foods were cooked, they were placed in a blender with half of the milk volume and the other ingredients, and blended for three minutes at medium speed. The remainder of the milk was added, and the mixture was blended again for another three minutes at medium speed. Stage III: the ready-to-eat formula was sieved three times through a fine mesh strainer, placed in a sterile plastic container, and stored in the refrigerator.

The proposed orange juice was not included in the formula, but only in the nutrient calculation and assessment. Juice should be recommended as a snack.

The pictures taken during the preparation of this formula and the hygiene requirements were described in a manual, which can be accessed online at <ecos-redenutri.bvs.br/tikidownload_file.php?fileld=899>.

The study blenderized enteral formula was assessed according to the Dietary Reference Intake (DRI) for men aged more than 51 years [20-22].

To analyze stability and homogeneity, the samples were placed in a glass beaker, refrigerated for 24 hours, and inspected visually.

Flow rate was assessed by counting how long it took for $200 \mathrm{~mL}$ of the formula to drip through the enteral feeding extension set. The formula was stored in a specific $300 \mathrm{~mL}$ plastic bag, which was hung on a hook one meter above from the drip chamber. Drip time was measured on two occasions, at Time 0 (TO), immediately after formula preparation, and at Time 3 (T3), after three hours of refrigeration at $4^{\circ} \mathrm{C}$. The formula was removed from the refrigerator and heated in a water bath for five minutes, which is enough time for it to reach room temperature $\left(25^{\circ} \mathrm{C}\right)$.
Osmolality was determined by a cryoscopic osmometer (Advanced Digmatic 3D2, Diversified Equipment Company, Inc., Lorton, Virginia, United States), and $\mathrm{pH}$ was determined by a digital $\mathrm{pH}$ meter ( $\mathrm{pH}$ Meter Tec - 2 Tecnal, Piracicaba, São Paulo, Brazil ), properly calibrated before the analyses of the samples conducted at room temperature.

The analyses included ash, moisture, energy, proteins, lipids, crude fiber, vitamin C, calcium, iron, magnesium, zinc, and phosphorus. Carbohydrate content was determined indirectly. All tests were repeated three times.

The study nutrients were measured by the following methods: protein by the Kjeldhal method, using the Jones factor and respecting ingredient ratios to convert total nitrogen into crude protein $[23,24]$; lipids by the Bligh-Dyer method; crude fiber by the acid digestion method; energy by bomb calorimetry; minerals by the inductively coupled plasma mass spectrometer ELAN DRCII (Perkin Elmer SCIEX, Toronto, Ontario, Canada); vitamin C by spectrophotometry using a wavelength of 520nm.

Energy density was given by dividing total energy content by the final volume of the formula and classified as recommended by Resolução da Diretoria Colegiada $n^{\circ} 21$, issued on May 13, 2015 [25].

The costs of the BTFFs were calculated by averaging the prices of the raw and processed food ingredients sold at three supermarkets of the city of Ribeirão Preto (SP).

The costs of the CEFs used for comparison with the BTFFs were calculated by averaging their prices at three specialized online stores, not including delivery. Three options of different brands of standard polymeric diets and diets for diabetics were chosen and their prices were averaged.

The list of replacement foods was created for rice, ground beef, carrot, and cow milk. The nutrients in the study foods were calculated by 
the nutrition software DietPro $5 i$ Profissional (A.S. SISTEMAS, Viçosa, Minas Gerais, Brazil), using data from the food composition table TACO [17], except for skim cow milk, whose nutritional data was provided by the table created by Philippi [18] and for the food supplement (Table 1), whose nutritional data were taken from the manufacturer's label.

The formula was tested in the laboratory changing one food at a time for the physical analyses of stability, homogeneity, and flow rate.

The distribution of the results was tested for normality by the Shapiro-Wilk test, using a significance level of $p<0.05$.

The results of the nutritional composition analyses of the BTFFs and the recommendation are normally distributed. The parametric test one-way Analysis of Variance (one-way ANOVA) was used, and the Tukey post hoc test verified the difference between the results. These analyses were performed by the statistical software Statistical Package for the Social Sciences (SPSS, Inc., Chicago, Illinois, United States) version 17.

The study project was approved by the Research Ethics Committee of the Clinics Hospital of Ribeirão Preto and the School of Medicine of Ribeirão Preto under Process $n^{\circ}$ 3970/2007.

\section{R E S U L T S}

The Blenderized Tube Feeding Formulas consisted mainly of fresh foods, most of them common to the Brazilian food habits. The final

Table 3. Physical analysis, proximate analysis, and energy density of the Blenderized Tube Feeding Formulas (BTFF) and the nutrient recommendations.

\begin{tabular}{|c|c|c|}
\hline Nutrients & RDA/AI/AMDR recommendations & BTFF \\
\hline Energy (kcal) & $2000 \mathrm{kcal}$ & $2337.0^{\#}$ \\
\hline \multicolumn{3}{|l|}{ Carbohydrate } \\
\hline g & $130 \mathrm{~g}$ & $206.4^{\#}$ \\
\hline$\%$ & $45-65 \%$ & 35.3 \\
\hline \multicolumn{3}{|l|}{ Protein } \\
\hline g & $56 \mathrm{~g}$ & $103.6^{\#}$ \\
\hline$\%$ & $10-35 \%$ & 17.7 \\
\hline \multicolumn{3}{|l|}{ Lipids } \\
\hline g & & 80.0 \\
\hline$\%$ & $20-35 \%$ & 30.8 \\
\hline \multirow[t]{2}{*}{ Crude fiber (g) } & $30 \mathrm{~g}$ & $17.3^{\#}$ \\
\hline & $14 \mathrm{~g} / 1000 \mathrm{kcal}$ & 7.4 \\
\hline Vitamin C (mg) & $90 \mathrm{mg}$ & $175.0^{\#}$ \\
\hline Iron (mg) & $8 \mathrm{mg}$ & $12.3^{\#}$ \\
\hline Calcium (mg) & $1200 \mathrm{mg}$ & $1057.0^{\#}$ \\
\hline Magnesium (mg) & $420 \mathrm{mg}$ & $328.2^{\#}$ \\
\hline Zinc (mg) & $11 \mathrm{mg}$ & $23.1^{\#}$ \\
\hline Osmolality (mOsm/kg) & - & 603.0 \\
\hline $\mathrm{pH}$ & - & 6.2 \\
\hline Flow rate & - & \\
\hline TO (minutes) & - & 21.0 \\
\hline T3 (minutes) & - & 31.0 \\
\hline Energy density (kcal/mL) & & 1.4 \\
\hline
\end{tabular}

Note: \#ndicates statistical difference from the recommendation according to the Tukey test $(p<0.05)$. 
volume was $1880 \mathrm{~mL}$, and orange juice was considered a snack. Physical analysis found that the formulation is homogeneous and stable after a 24-hour refrigeration period, hypertonic, and slightly acidic, and it has a flow rate compatible with gravity drip. The formulas also had high energy density at $1.4 \mathrm{kcal} / \mathrm{mL}$ (Table 3 ).

When the values found by proximate analysis are compared with the DRIs, the protein, lipid, vitamin C, iron, and zinc contents reached the recommended levels. The carbohydrate, fiber, magnesium, and calcium contents were below the recommended levels. All results, except for lipids, were statistically different from the recommended values (Table 3).

The replacement list was created for rice, ground beef, raw carrots, and cow milk. One tablespoon of rice can be replaced by two tablespoons of short-cut pasta; one full tablespoon of ground beef can be replaced by

Table 4. Nutritional composition of the standard Blenderized Tube Feeding Formula (BTFF), calculated using a food composition table) with the proposed replacement foods, final volumes, and flow rates.

\begin{tabular}{|c|c|c|c|c|c|c|c|c|c|c|c|}
\hline Nutrients & $\operatorname{Rec}$ & BTFF & Pas & $\mathrm{Ch}$ & Egg & $\mathrm{Zu}$ & Pum & Cha & Beet & Pod & SE \\
\hline Energy (kcal) & 2000.0 & 2106.0 & 2009.0 & 1990.0 & 1925.0 & 2002.0 & 2001.0 & 2008.0 & 2003.0 & 2008.0 & 2047.0 \\
\hline \multicolumn{12}{|l|}{ Carbohydrate } \\
\hline g & 130.0 & 286.3 & 273.6 & 267.1 & 269.2 & 266.8 & 263.3 & 268.5 & 268.2 & 268.9 & 221.8 \\
\hline$\%$ & & 54.4 & 54.4 & 53.7 & 55.9 & 53.3 & 52.6 & 53.4 & 53.5 & 53.6 & 43.3 \\
\hline \multicolumn{12}{|l|}{ Proteins } \\
\hline g & 56.0 & 105.7 & 104.2 & 118.5 & 89.5 & 105.9 & 104.9 & 105.5 & 104.8 & 105.9 & 97.3 \\
\hline$\%$ & & 20.1 & 20.7 & 23.8 & 17.9 & 21.1 & 21.0 & 21.0 & 20.9 & 21.0 & 19.0 \\
\hline Lipids (\%) & $20.0-35.0$ & 26.7 & 28.0 & 25.0 & 29.0 & 29.2 & 28.9 & 28.9 & 28.9 & 28.9 & 42.6 \\
\hline \multicolumn{12}{|l|}{ Fibers } \\
\hline g & 30.0 & 18.5 & 16.1 & 17.7 & 18.5 & 18.6 & 15.2 & 16.8 & 17.0 & 18.6 & 29.8 \\
\hline g/1000kcal & 14.0 & 8.8 & 8.0 & 8.9 & 9.6 & 9.3 & 7.6 & 8.4 & 8.5 & 9.3 & 14.9 \\
\hline Calcium (mg) & 1200.0 & 2182.8 & 2320.4 & 2319.6 & 2379.4 & 2342.5 & 2330.8 & 2319.6 & 2321.8 & 2355.1 & 670.5 \\
\hline Magnesium (mg) & 420.0 & 402.1 & 538.2 & 552.4 & 553.3 & 578.6 & 556.8 & 554.1 & 565.9 & 569.2 & 609.8 \\
\hline Manganese (mg) & 2.3 & 2.3 & 1.7 & 2.1 & 2.3 & 2.5 & 2.5 & 2.5 & 2.7 & 2.6 & 4.8 \\
\hline Phosphorus (mg) & 700.0 & 2076.7 & 1814.4 & 1986.0 & 1886.6 & 1897.4 & 1896.2 & 1872.0 & 1881.2 & 1892.2 & 418.0 \\
\hline Iron (mg) & 8.0 & 13.8 & 13.8 & 11.0 & 12.5 & 14.1 & 14.6 & 13.8 & 13.8 & 15.0 & 15.9 \\
\hline Sodium (mg) & 1300.0 & 1524.3 & 1242.2 & 1516.5 & 1603.7 & 1516.4 & 1773.6 & 1517.5 & 1591.3 & 1517.4 & 837.6 \\
\hline Potassium (mg) & 4700.0 & 4074.1 & 3527.5 & 3614.9 & 3537.2 & 3851.3 & 3794.7 & 3534.5 & 3693.4 & 3762.0 & 566.6 \\
\hline Copper (mg) & 0.9 & 1.4 & 1.3 & 1.3 & 1.3 & 1.4 & 1.5 & 1.4 & 1.4 & 1.5 & 2.3 \\
\hline Zinc (mg) & 11.0 & 21.7 & 19.1 & 12.7 & 13.0 & 20.4 & 20.1 & 19.9 & 20.2 & 20.2 & 19.3 \\
\hline Vit. A ( $\mu$ g RAE) & 900.0 & 1875.1 & 1875.1 & 1875.1 & 2047.0 & 285.3 & 1830.8 & 228.9 & 225.1 & 295.0 & 1650 \\
\hline Thiamin (mg) & 1.2 & 1.3 & 1.3 & 1.5 & 1.3 & 1.3 & 1.3 & 1.3 & 1.3 & 1.3 & 0.2 \\
\hline Riboflavin (mg) & 1.3 & 4.4 & 4.4 & 4.0 & 4.0 & 4.4 & 4.5 & 4.4 & 4.4 & 4.5 & 0.5 \\
\hline Pyridoxin (mg) & 1.7 & 1.0 & 1.0 & 1.0 & 1.1 & 1.1 & 1.0 & 1.0 & 1.1 & 1.1 & 0.8 \\
\hline Niacin (mg) & 16.0 & 33.1 & 33.1 & 42.0 & 31.3 & 29.8 & 30.4 & 29.8 & 29.8 & 30.4 & 5.8 \\
\hline Vit. C (mg) & 90.0 & 28.9 & 27.7 & 28.2 & 28.9 & 105.8 & 34.5 & 74.0 & 27.0 & 36.2 & 21.6 \\
\hline Final volume & & 1880.0 & 1860.0 & 1880.0 & 1880.0 & 1940.0 & 1840.0 & 1880.0 & 1820.0 & 1800.0 & 1880.0 \\
\hline \multicolumn{12}{|l|}{ Flow rate } \\
\hline T0 minutes & & 21 & 15 & 12 & 5 & 26 & 24 & 15 & 13 & 7 & 11 \\
\hline T3 minutes & & 31 & 13 & 9 & 4 & 21 & 20 & 12 & 11 & 6 & 11 \\
\hline
\end{tabular}

Note: Rec.: Nutritional recommendation; Pas: Pasta; Ch: Chicken; Zu: Zucchini; Pum: Pumpkin; Cha: Chayote; SE: Soybean Extract; T0: Time 0; T3: Time 3; RAE: Retinol Activity Equivalents; Vit.: Vitamin. 
one full tablespoon of chicken breast or half a chicken egg; one full tablespoon of carrots can be replaced by one full tablespoon of pumpkin, zucchini, pod, or beet, or two full tablespoons of chayote; and one $190 \mathrm{~mL}$ glass of cow milk can be replaced by the same amount of lactosefree cow milk or ready-to-drink soy milk, or one tablespoon of soy extract powder or one tablespoon of fortified soy milk powder.

The replacement foods result in minor changes in the nutritional composition of the standard BTFF. The greatest changes are the smaller energy content of diets containing chicken or chicken egg; lower vitamin A content in diets containing zucchini, beet, chayote, and pod; higher vitamin $\mathrm{C}$ content of diets containing zucchini and chayote; and higher fiber content in diets containing soy extract (Table 4).

All blenderized diets using the replacement foods are homogeneous and stable after a 24-hour refrigeration period.

The Blenderized Tube Feeding Formulas cost $R \$ 12.3 \pm 1.4$ per day. The foods that most contribute to the cost are milk and the nutritional supplement. Compared with the standard CEF, the BTFF is on average $70 \%$ cheaper (Table 5 ).

\section{DISCUSSION}

The Blenderized Tube Feeding Formulas had appropriate stability, homogeneity, $\mathrm{pH}$, flow rate, and osmolality. These characteristics are important to prevent feeding tube obstruction and provide adequate gastric motility.
High Blenderized Tube Feeding Formulas osmolality is explained mainly by the use of sugar as the carbohydrate source, chosen because of its availability in Brazilian households and low cost. The use of enteral formulas with high osmolality (above $600 \mathrm{mOsm} / \mathrm{kg}$ ) is not contraindicated, but they must be administered in the stomach at a slow drip rate [26]. In this case, BTFFs can be used safely as long as the caregiver is properly instructed with respect to these aspects. In case of intolerances, sugar should be replaced by another carbohydrate source, such as maltodextrin or corn glucose, used in other studies $[9,27]$.

The nutrient inadequacies found in the BTFFs may stem from loss of nutrients and/ or interaction between nutrients during food processing because the carbohydrate, lipid, calcium, and magnesium contents determined by proximate analysis (Table 3) were very different from those obtained from food composition tables (Table 4), whose values were compliant with the DRIs.

Similar results have been found in the scientific literature, for example, by the study conducted by Felício et al. [10], who found a large energy density difference between proximate analysis and the estimated value given by two Brazilian food composition tables, and by Sousa et al. [11], who also found differences in the carbohydrate, protein, and lipid contents measured by proximate analysis and the same contents provided by food composition tables.

The calcium content of the study BTFF is $88 \%$ of the recommended value. Although it is

Table 5. Daily and monthly costs of $2000 \mathrm{~mL}$ of the blenderized tube feeding formulas and commercial enteral formulas.

\begin{tabular}{|c|c|c|c|c|c|c|}
\hline \multirow{2}{*}{ Feeding formula } & \multicolumn{3}{|c|}{ Daily cost $(R \$)^{*}$} & \multicolumn{3}{|c|}{ Monthly cost $(R \$)^{*}$} \\
\hline & M & & SD & M & & SD \\
\hline Blenderized Tube Feeding Formula (BTFF) & 12.3 & \pm & 1.4 & 367.7 & \pm & 41.2 \\
\hline Standard commercial enteral formula & 40.8 & \pm & 1.9 & 1223.5 & \pm & 57.1 \\
\hline
\end{tabular}

Note: *Prices collected in August 2016, Ribeirão Preto (SP).

M: Mean; SD: Standard Deviation. 
below the value established by the DRI, it may still be adequate for a large number of people as the adequate intake value may exceed the Recommended Daily Allowance value [22].

The low crude fiber content found by proximate analysis, a challenging problem in BTFFs, was also found by Von Atzingen et al. [28], who found 8g/L, Araújo \& Menezes [7], who found $3.1 \mathrm{~g} / \mathrm{L}$, and Felício et al. [10], who found $5 \mathrm{~g} / \mathrm{L}$ in the standard BTFF. This is due to the tendency of certain fibers to jellify, which increases the consistency of the diet and reduces the homogeneity and stability in mixed solutions, causing feeding tube obstruction. Therefore, their use is unviable for enteral feeding.

Fibers are very important for health, but in enteral nutrition their use has been discussed for many years, and many studies do not reach a consensus for their recommendation, especially for critical and postoperative patients [29]. The main concern in these cases is related to the occurrence of diarrhea, but patients who need long-term enteral feeding have a higher prevalence of constipation, a situation in which the use of fibers has been very important. Professionals who work in household nutrition care should decide and individualize the fiber content required by a patient based on the patient's symptoms. Alternatives may be used to increase fiber intake, such as the administration of juices containing laxative foods as snacks and the use of fiber supplements, available in specialized stores.

It is critical to emphasize that the nutrients in regular foods vary, and one day of food intake hardly ever provides all the nutrients required by an individual. The results of the Family Budget Survey (POF) 2008-2009 [30] are good examples of this fact as the Brazilian diet is poor in many nutrients, such as fibers, pyridoxine, cobalamin, vitamin D, vitamin E, calcium, and magnesium. Thus, the caregiver should be advised to vary the foods in the diet using the replacement list as guide, which would provide a greater variety of nutrients and bioactive compounds.
With respect to cost, the BTFFs were inexpensive, representing monthly $41.8 \%$ of the minimum salary. On the other hand, CEFs have a monthly cost of $139.0 \%$ of the minimum salary, making them inaccessible to many.

The low cost of BTFFs has also been reported by Von Atzingen \& Silva [28], who found a cost of $\mathrm{R} \$ 4.00$ for the diet with hydrolyzed beef and chicken protein, and $\mathrm{R} \$ 5.40$ for the diet with hydrolyzed turkey protein; and by Henriques \& Rosado [8], who found a mean cost of $R \$ 6.12$, and by Lima et al. [12], who found a cost of $R \$ 3.08$ for each $2000 \mathrm{kcal}$ of the diet.

It is important to emphasize that food does more than to satisfy the body's requirements, it also satisfies psychosocial requirements. Restricting oral food intake also restricts the pleasure of tasting foods and of integration and exchange of affection during a meal with family and friends. Thus, the use of habitual foods for the preparation of a BTFF may help to maintain the emotional relationship with food.

\section{CONCLUSION}

Blenderized Tube Feeding Formulas can be an excellent choice for patients who need home enteral feeding as they were made of habitual foods, have nutritional and physical quality, and are inexpensive.

Additionally, the possibility of varying the foods that compose the diet, as instructed by the replacement list, contributes to the supply of bioactive nutrients and compounds, keeps the diets affordable as the caregiver is free to choose the foods available in the household, and may satisfy psychosocial needs as the patient enjoyed eating the chosen foods.

Training in Good Manufacturing Practices is needed to reduce the risk of microbiological contamination, and a multi-professional team needs to assess patients' nutritional status, and the clinical and social statuses of the patients and their household. 


\section{A C KNOWLEDGMENTS}

We thank Conselho Nacional de Desenvolvimento Científico e Tecnológico, for the grant, Guilherme Vanucchi and Cristiana Cortes de Oliveira for their collaboration in the chemical analyses, physical tests, and preparation of the blenderized diets formulated in this study.

\section{CONTRIBUTORS}

APL BENTO participated in data collection and tabulation, discussed the results, and wrote the article. RW DIEZ GARCIA and AA JORDÃO JÚNIOR participated in the creation of the experimental strategy and data tabulation, discussed the results, and wrote the article.

\section{RE FER E N CES}

1. DeLegge $\mathbf{M H}$. Enteral access in home care. J Parenter Enteral Nutr. 2006;30(Suppl.1):13-20. https://doi.org.10.1177/01486071060300S1S13

2. Bréton JO, Ruesca PB, Laborda SG, Nogueras EF. Evaluación de un programa de nutrición enteral domiciliaria. Endocrinol Nutr. 2002;49(6):179-84. https://doi.org/10.1016/S1575-0922(02)74453-7

3. Villares JMM. La práctica de la nutrición artificial domiciliaria en Europa. Nutr Hosp. 2004;19(2):59-67.

4. Zaban ALRS, Novaes MRCG. Demographic, epidemiological and nutritional profile of elders in home enteral nutritional therapy in Distrito Federal, Brazil. Invest Clin. 2009;50(3):347-57.

5. Horst MA, Lajolo E. Biodisponibilidade de compostos bioativos de alimentos. In: Cozzolino SMF. Biodisponibilidade de nutrientes. $2^{\mathrm{a}}$ ed. São Paulo: Manole; 2007. p.697-735.

6. Carratu E, Sanzini E. Sostanze biologicamente attive presenti negli alimenti di origine vegetale. Ann Ist Super Sanitá. 2005;41(1):7-16.

7. Araújo EM, Menezes HC. Formulações com alimentos convencionais para nutrição enteral ou oral. Ciênc Tecnol Aliment. 2006;26(3):533-8. https:// doi.org/10.1590/S0101-20612006000300008

8. Henriques GS, Rosado GP. Formulação de dietas enterais artesanais e determinação da osmolalidade pelo método crioscópico. Rev Nutr. 1999;12(3):225-32. http://doi.org/10.1590/S14 15-52731999000300003
9. Von Atzingen MC, Silva MEMP. Características físico químicas de dietas enterais artesanais com hidrolisado protéico de carne. Alim Nutr. 2007;18(2):183-9.

10. Felício BA, Pinto ROM, Pinto NAVD, Silva FD. Food and nutritional safety of hospitalized patients under treatment with enteral nutrition therapy in the Jequitinhonha Valley, Brazil. Nutr Hosp. 2012;27(6):2122-9. https://doi.org/10.3305/ nh.2012.27.6.6118

11. Sousa LRM, Ferreira SLR, Schieferdecker MEM. Physicochemical and nutritional characteristics of handmade enteral diets. Nutr Hosp. 2014;29(3):568-74. https://doi.org/10.3305/NH.20 14.29.3.7083

12. Lima VS, Souza FCA, Aguiar JPL, Yuyama LKO. Composição nutricional de dieta enteral artesanal a partir de alimentos convencionais do Município de Coari, Estado do Amazonas, Brasil. Rev PanAmaz Saúde. 2015;6(2):29-36. https://doi.org/10. 5123/S2176-62232015000200004

13. Medina JM, Nascimento GGF, Oliveira MRM, Marques MR. Contaminação microbiológica de dietas enterais. Rev Bras Nutr Clin. 2008;23(4):262-9.

14. Santos MIS, Tondo EC. Determinação de perigos e pontos críticos de controle para implantação de sistema de análise de perigos e pontos críticos de controle em lactário. Rev Nutr. 2000;13(3):211-22. https://doi.org/10.1590/\$1415-5273200000030 0008

15. Oliveira MH, Bonelli R, Aidoo KE, Batista CRV. Microbiological quality of reconstituted enteral formulations used in hospitals. Nutrition. 2000;16(9):729-33.

16. Carvalho-Filho EV, Aquino JS, Donato NR, Sousa PPR, Silva JA. Monitoramento fisíco-químico e microbiológica de dietas enterais em unidade hospitalar pública da Região Nordeste do Brasil. Alim Nutr. 2008;19(2):145-51.

17. Núcleo de Estudos e Pesquisas em Alimentação. Tabela Brasileira de Composição de Alimentos: $4^{a}$ ed. rev. amp. Campinas: Unicamp; 2011.

18. Philippi ST. Tabela de Composição de Alimentos: suporte para decisão nutricional. $5^{\mathrm{a}}$ ed. São Paulo: Manole; 2015.

19. Ornellas LH. Técnica dietéica, seleção e preparo de alimentos. São Paulo: Atheneu; 2007.

20. Institute of Medicine. Dietary Reference Intakes for vitamin A, vitamin $\mathrm{K}$, arsenic, boron, chromium, copper, iodine, iron, manganese, molybdenum, nickel, silicon, vanadium, and zinc. Washington (DC): Institute of Medicine; 2000.

21. Institute of Medicine. Dietary Reference Intakes for vitamin C, vitamin e, selenium, and carotenoids. Washington (DC): Institute of Medicine; 2000. 
22. Institute of Medicine. Dietary Reference Intakes for energy, carbohydrate, fiber, fat, fatty acids, cholesterol, protein, and amino acids (macronutrients). Washington (DC): Institute of Medicine; 2005.

23. Association of Official Analytical Chemists. Official methods of analysis of the Association of Official Analytical Chemists. 16th ed. Arlington: AOAC; 1995. v.1.

24. Matiotti F, Tomé D, Mirand PP. Converting nitrogen into protein: Beyond 6,25 and Jone's factors. Crit Rev Food Sci Nutr. 2008;48(2):177-84. https://doi. org/10.1080/10408390701279749

25. Agência Nacional de Vigilância Sanitária. Resolução da Diretoria Colegiada - RDC n²1, de 13 de maio de 2015. Diário Oficial da União. 2015 15 maio [acesso 2017 fev 28]; Seção 1(91):28-31. Disponível em: http://crn3.org.br/Areas/Admin/ Content/upload/file-0711201562603.pdf

26. Agência Nacional de Vigilância Sanitária. Resolução $n^{\circ} 449$, de 9 de setembro de 1999. Aprova o regulamento técnico referente a alimentos para nutrição enteral. Diário Oficial da União.1999 13 set.

27. Menegassi B, Sant'Ana LS, Coelho JC, Martins OA, Pinto JPAN, Braga Costa TM, et al. Caracte- rísticas físico-químicas e qualidade nutricional de dietas enterais não-industrializadas. Alim Nutr. 2007; 18(2):127-32.

28. Von Atzingen MC, Silva MEMP. Desenvolvimento e análise de custo de dietas enterais artesanais à base de hidrolisado protéico de carne. Rev Bras Nutr Clin. 2007;22(3):210-3.

29. Tarleton SM, Kraft CA, DiBaise JK. Fiber-enriched enteral formulae: Advantageous or adding fuel to the fire? Pract Gastroenterol. 2013;(124):11-22. [cited 2017 Mar 6] Available from: https://med. virginia.edu/ginutrition/wpcontent/uploads/ sites/199/2014/06/Parrish_Dec_13.pdf

30. Instituto Brasileiro de Geografia e Estatística. Pesquisa de Orçamentos Familiares 2008-2009: análise do consumo alimentar pessoal no Brasil. Brasília: IBGE; 2011 [acesso 2014 fev 20]. Disponível em: http://www.ibge.gov.br/home/estatistica/ populacao/condicaodevida/pof/2008_2009_ analise_consumo/pofanalise_2008_2009.pdf

Received: September 12, 2016 Final version: March 11, 2017 Approved: May 15, 2017 